\title{
Дискусійні статті
}

УДК $618.2+159.9+616-01$

\author{
I.C. Тимків
}

\section{ПСИХОЛОГІЧНІ ПРОБЛЕМИ ВАГІТНОСТІ ТА ПЕРИНАТАЛЬНОГО ПЕРІОДУ}

ДВНЗ «Івано-Франківський національний медичний університет»

Резюме. Одним із важливих завдань, що стоять перед суспільством у цілому і медициною зокрема, $\epsilon$ формування i розвиток пренатальної культури (або культури батьківства), яка допоможе виростити покоління, що відноситься до народження дитини як до природної і радісної події у своєму житті. Пологи для кожної жінки - очікуваний, таємничий i незабутній етап життя. Болючі відчуття швидко забудуться - так влаштована жінка, і залишиться в пам'яті тільки пре- красний момент народження маленького дива. Щоб пологи пройшли оптимально, варто приділити особливу увагу психологічній підготовці вагітної. У статті розглядається проблематика відношення жінки до вагітності, пологів та народження дитини. Наведені дані можуть використовуватися при формуванні програм навчання у школах материнства та батьківства.

Ключові слова: вагітність, психологія, пацієнт.

У психології, як науці, виокремлено найсокровенніший період у житті жінки - це час виношування дитини, що є предметом розгляду перинатальної психології. Період досить короткий. Але, якщо задуматися скільки відбувається змін у житті, фізичній та емоційній сфері жінки і ще до цього додати появу та розвиток нового життя, то очевидно, що навантаження на цей малий проміжок часу досить велике.

За походженням вагітність поділяють на випадкову i заплановану. Випадковою $є$ та вагітність, яка є небажаною або несподіваною для подружжя. Вагітність буває запланованою обома партнерами і планованою тільки жінкою. Мотиви збереження вагітності головним чином залежать від особистісних установок жінки і соціальних нормативів суспільства, що визначаються культурно-історичним часом, в якому вона живе $[10,11]$.

Н.В. Боровікова і С.А. Федоренко [2] виділили наступні мотиви збереження вагітності.

1. Вагітність заради дитини - найбільш позитивний мотив, який відбиває психологічну потребу жінки в материнстві і готовність до нього. Він характерний для соціально зрілих осіб, які особистісно відбулися, а також одиноких жінок у віці.

2. Вагітність від коханої людини - сприяє створенню високого рівня адаптивності жінки до вагітності. Майбутня дитина виступає як частинка коханої людини, символ «світлого» минулого або сьогодення, який жінка хоче пронести через усе життя.

3. Вагітність як відповідність соціальним очікуванням - цей мотив зазвичай притаманний молодим дівчатам із забезпечених сімей або тих, у котрих літні батьки ще не мають онуків (тобто вони народжують дитину не для себе, а для своїх батьків). Слід окремо виділити вагітність «для чоловіка». При цьому дитина народжується не стільки у відповідності зі своїм бажанням, скільки на прохання чоловіка.

(C) І.С. Тимків, 2014

182
4. Вагітність як протест - це «вагітність на зло» значимому чоловікові або батькам. Така поведінка властива молодим дівчатам. Вагітність носить характер протесту, виклику, протистояння світу дорослих, є для жінки драматичною і часто важко травмує ії психіку.

5. Вагітність заради збереження відносин коли жінка зважується на народження дитини, щоб внести щось нове в близькі стосунки з чоловіком і утримати його поруч.

6. Вагітність як відмова від минулого - у цьому випадку вагітність може розцінюватися самою жінкою як бажання відчути себе особистістю, закреслити своє минуле.

7. Вагітність заради збереження власного здоров'я - мотив, зумовлений боязню заподіяти шкоду своєму здоров'ю абортом або втратити можливість дітонародження в майбутньому. Описані мотивації не існують у психіці жінки в чистому вигляді, а взаємно доповнюють одна одну на тлі домінування однієї з них.

Стиль переживання жінкою вагітності включає в себе: фізичне та емоційне переживання моменту ідентифікації вагітності, переживання симптоматики вагітності, динаміка переживання симптоматики по триместрах вагітності; переважне тло настрою в ці періоди; переживання першого ворушіння і ворушінь протягом усієї другої половини вагітності; зміст активності жінки в третій триместр вагітності $[4,8]$.

Розуміння жінкою своєї ролі в пологах i вміння іiі реалізувати, а також позитивне налаштування - «зможу» - стають тими інструментами, які допомагають народити здорову дитину. Розуміння формує впевненість, залишки страхів зникають після обговорення і розвінчання типових фобій. Поза сумнівом, обізнаність і обгрунтована впевненість у своїх силах відіграють важливу роль у вирішенні будь-яких життєвих завдань, особливо таких важливих, як народження люди- 
ни. Страхи, тривога, паніка - погані супутники завжди, а в пологах - просто небезпечні.

Напередодні пологів переживає кожна вагітна жінка. Що ж потрібно робити, щоб підготуватися до народження дитини психологічно? На питання про те, що відіграє важливу роль при народженні дитини, більшість досвідчених акушерів відповість - мислення, думки, поведінка роділлі!

Безпосередньо перед пологами наростає тривога, проявом якої може бути гіперактивність вагітної, яка бажає прискорити події. Афективні розлади в останньому триместрі спостерігаються в $\quad 60-80 \%$ випадків. Описано феномен «перинатальної тривоги» і їі вплив на результат вагітності. У вагітної, як правило, виявляється кілька видів тривоги: фізична (коли жінка тяжко переносить фізичні аспекти вагітності); страх за долю плода; страх перед пологами; страх перед необхідністю догляду за новонародженим; страх перед годуванням немовляти $[1,3,15]$.

Ймовірність упоратися 3 фобіями зростає, якщо оточення майбутньої мами транслює їй упевненість і спокій. Цим оточенням у першу чергу є батько дитини, мати породіллі і їі лікар, тобто це ті люди, які повинні вселяти довіру й гарантувати підтримку. Якщо на всьому протязі вагітності жінка перебувала в такій обстановці, яка допомагала впоратися з її тривогами, одержувала досить психологічної й інформаційної підтримки, проходила підготовчі заняття 3 підготовки до пологів разом із чоловіком, то пологи мають всі шанси сприятливого перебігу.

Всі фобії мінімалізуються при усвідомленому відношенні жінки до пологів та навчанні ії деяким прийомам керування своїм станом і при збереженні контакту з дитиною. Це сприяє збереженню симбіотичної єдності 3 плодомновонародженим, мобілізації сил і сприятливо впливає на розвиток пологової діяльності. Якщо цей період проходить сприятливо і тандем «матидитя» злагоджено проходить перешкоди, то це сприяє позитивному досвіду дитини в плані проходження через труднощі, прийняття рішення, відкритості новому невідомому. У разі ж негативного проходження через цей період формується досвід «відсутності виходу» [9, 13].

Окремо необхідно зупинитися на існуючій сьогодні проблемі - високій частоті кесаревого розтину. Одразу слід відкинути ті випадки, коли до оперативного втручання є медичні показання. Але сьогодні вже нікого в пологовому стаціонарі не здивують сучасні батьки, які самостійно залюбки погоджуються на подібну процедуру, «випрошують» оперативне втручання. При цьому, їм слід зважити всі «за» і «проти» такого вибору. За радість материнства передбачена певна «ціна» - труднощі пологів. У кожного вона своя. Та чи повинна новонароджена дитина розплачуватися майбутніми психологічними проблемами 3 тієї лише причини, що мати не хоче пройти через досвід природних пологів?
Дитина, яка народилася внаслідок кесаревого розтину, приходить у світ із певними підсвідомими установками. Оперативне втручання (а не природні пологи) є швидким і шоковим для малюка, позбавляє його досвіду переживання ситуації безвиході («рай» зруйнувався, виникло напруження і дискомфорт, а виходу немає) і боротьби за себе. Дитина не отримує відчуття меж власного тіла та на психічному рівні - меж переживання стресу, болю, страждання. У цьому сенсі проходження дитини через досвід природних пологів $\epsilon$ для неї важливим. Новонароджені діти дуже чутливі до атмосфери в операційній. Від того, яким у дитини буде переживання власного народження (перші дотики, тілесні відчуття, рефлекси), складеться емоційне сприйняття цього світу: від теплого і сповненого любові до небезпечного і травмуючого. Тому в пологових центрах після проведення кесаревого розтину викладають немовля на живіт батькові. Медична сторона цієї технологіїзаселення шкірних поверхонь дитини «сімейними» бактеріями, психологічна складова - створення атмосфери любові і прийняття. Рідний батько відчуватиме до дитини щось інше, ніж чужа медсестра чи лікар, для яких пологи це звичайна робота.

Дуже важливе значення в психологічній підготовці до пологів має підготовка до партнерських пологів. Вона здійснюється в школі при жіночій консультації. Багато століть вагітність і пологи були суто жіночим досвідом, до якого чоловік не мав права доступу. У сучасному ж суспільстві протягом короткого строку відбулося ламання стереотипу, пов'язаного 3 тим, що вважати жіночим, а що - чоловічим.

Не потрібно намагатися змусити чоловіка піти на пологи, мотивуючи це тим, що «хай дивиться, як я мучуся» або «не мені одній страждати, хай і він бере участь». Швидше за все, «насильницьки» приведений чоловік не відчує нічого, окрім жаху і відрази, а потім ставитиме дружині в приклад «нормальних» жінок, які народжували самі.

Партнерські пологи з чоловіком, швидше за все, підійдуть парам, в яких: не соромно погано виглядати при «другій половині»; прийнято відкрито ділитися своїми переживаннями; немає заборонених тем і табу; чоловік діє розумно навіть у критичних ситуаціях, не піддається паніці; у подружжя $\epsilon$ готовність всю відповідальність, ласку і турботу до малюка ділити навпіл. Однозначно, що слід утриматися від присутності чоловіка при пологах, якщо: жінка не може розслабитися у присутності іншої людини; жінка звикла всі проблеми вирішувати сама і чия-небудь присутність їй заважатиме; чоловік надмірно емоційний і схильний до паніки, якщо він не може себе контролювати і зібратися за критичної ситуації; у подружжя не прийнято ділитися переживаннями; чоловік інфантильний і не вміє брати на себе відповідальність.

Бути присутнім або не бути присутнім у момент самого пологового процесу - питання, що 
не має однозначного рішення. Безумовно, що рішення про спільні пологи повинно бути прийняте спільно. Якщо є найменші розбіжності, то краще відразу ж залишити цю ідею, в іншому випадку додаткове емоційне навантаження під час пологів може негативно позначитися на їхньому перебігу. Кожна родинна пара індивідуальна. Не варто йти народжувати разом тому, що це робить багато людей, або тому, що ваші знайомі поступили таким чином. Народження дитини радісна, і в той же час дуже значима подія в житті кожної сім'ї. Воно змінює обох батьків: і мати, і батько починають новий етап своїх стосунків разом із маленьким чудом. I лише усвідомлене, вільне рішення спільно допомогти дитині з'явитися на світ принесе користь і йому, і батькам.

Хоч як це не банально, але, якщо допологовий період проходив сприятливо, то під час пологів для жінки не так важливо, є присутнім чоловік чи ні, оскільки в цей момент вона зосереджена на своїй першочерговій місії - випустити у світ нове життя.

3 народженням дитини виняткового значення набуває материнська любов, яка є важливою завжди, але особливо на початковому етапі життя людини, оскільки цей період $є$ найбільш сенситивним для формування базових основ особистості і ставлення до світу $[5,6]$.

А.I. Захаров [7] виділяє фактори, що сприяють дозріванню і прояву материнського інстинкту у вигляді подальшої турботи про дітей і любові до них:

- «праобраз материнства»: важливість інстинкту материнства і батьківства у прабатьків і батьків;

- бажання мати дітей, установка на них: при небажаності дитини материнський інстинкт може не виявитися;

- «позитивний відгук» на вагітність: заздалегідь планований період зачаття, очікувана затримка місячних отримують адекватний позитивний емоційний відгук;

- ніжність до життя, яке зароджується: перше ворушіння плода створює хвилююче відчуття причетності, бажання бути з дитиною;

- почуття жалю і співчуття до дитини: перший крик новонародженого викликає в матері почуття величезної радості, як у творця нового життя, разом із почуттям полегшення і задоволення від завершення пологів;

- відчуття близькості 3 дитиною: перше прикладання до грудей означає перший досвід співучасті в житті дитини.

Таким чином, із психологічної точки зору робота в період вагітності повинна бути сфокусована на наступних моментах $[12,14]$ :

- ознайомлення $з$ фізіологічними аспектами перебігу вагітності і пов'язаними з ними змінами в даний період ;

- надання майбутній матері інформації про можливі емоційні і поведінкові особливості жінок у період виношування дитини;
- прояснення актуальних бажань і очікувань щодо свого життя і життя майбутньої дитини (побудова «прогностичного сценарію» усіма членами сім'ї в очікуванні дитини);

- співвіднесення материнського «я» 3 уявленнями і знаннями про себе, власну особистість, прийнятні соціальні ролі.

Народження дитини - дуже важлива, емоційно насичена подія в житті будь-якої сім'ї. Все більше сучасних пар, які очікують на появу малюка, усвідомлюють, що підготовка до цієї події виходить далеко за рамки купівлі одягу для немовляти. Пологи і материнство - відповідальні і серйозні завдання, що вимагають від батьків готовності фізичної, інформаційної, психологічної. Сучасна культура батьківства пропонує вагітним парам велику кількість різноманітних можливостей для того, щоб свідомо і з задоволенням прожити дивовижні дев'ять місяців, налагодити взаєморозуміння і міцний контакт із малюком, підготуватися до пологів і успішного материнства.

\section{Література}

1. Бех І.Д. Виховання особистості / І.Д. Бех. - К.: Либідь, 2003. $-350 \mathrm{c}$.

2. Боровикова Н.В. Адаптация к новому образу "Я" у беременных женщин / Н.В. Боровикова, Е.П. Кораблина, С.А. Федоренко // Вестн. Балт. акад., 1998. Вып. 15. - С. 81-86.

3. Брусиловський A.I. Життя до народження / А.І. Брусиловський. - К.: Знання, 1991. - 224 с.

4. Брутман В.И. Динамика психологического состояния женщин во время беременности и после родов / В.И. Брутман, Г.Г. Филиппова, И.Ю. Хамитова // Вопр. психол. - 2002. - № 1. - С. 59-68.

5. Брутман В.И. Формирование привязанности матери к ребенку в период беременности / В.И. Брутман, М.С. Родионова // Вопр. психол. - 1997. - № 6. C. 38-47.

6. Драпкин Б.3. Психотерапия материнской любовью/ Б.З. Драпкин. - М.: ДеЛипринт, 2004. - 230 с.

7. Захаров А.И. Дневные и ночные страхи у детей А.И. Захаров. - СПб.: СОЮЗ, 2000. - 378 с.

8. Захарова Є.В. Особистісні зміни, пов'язані з появою дитини / Є.В. Захарова // Ж. практ. психолога. 2003. - № 4-5. - С. 38-45.

9. Кулагина И.Ю. Возрастная психология: Полный жизненный цикл развития человека: уч. пособие / И.Ю. Кулагина, В.Н. Колюцкий. - М.: ТЦ "Сфера", 2001. - $150 \mathrm{c}$

10. Малкина-Пых И.Г. Психосоматика: Справочник практического психолога. / И.Г. Малкина-Пых. - М.: Эксмо, 2005. - 992 с

11. Овчарова Р.В. Психология родительства / Р.В. Овчарова. - М.: Академия, 2005. - 368 с.

12. Подобед И.Д. Коррекция психовегетативного статуса беременных и её роль в снижении перинатального риска / И.Д. Подобед: материалы III Росс. форума ["Мать и дитя"]. - М.: МИК, 2001. - С. 480-482.

13. Рыбалко Е.Ф. Возрастная и дифференциальная психология / Е.Ф. Рыбалко. - СПб.: Питер, 2001. - 850 с.

14. Рыжков В.Д. Психопрофилактика и психотерапия функциональных расстройств нервной системы у беременных женщин / В.Д. Рыжков // Мед. помощь. 1996. - № 3. - С. 33-36.

15. Филиппова Г.Г. Психология материнства / Г.Г. Филиппова. - М.: Издат. Инст. психотерапии, 2002. $-240 \mathrm{c}$ 


\section{ПСИХОЛОГИЧЕСКИЕ ПРОБЛЕМЫ БЕРЕМЕННОСТИ И ПЕРИНАТАЛЬНОГО ПЕРИОДА}

\section{И.С. Тымкив}

Резюме. Одной из важных задач, стоящих перед обществом в целом и медициной в частности, является формирование и развитие пренатальной культуры (или культуры родительсва), которая поможет вырастить поколение, относящееся к рождению ребенка как к естественному и радостному событию в своей жизни. Роды для каждой женщины - ожидаемый, таинственный и незабываемый этап жизни. Болевые ощущения быстро забудутся - так устроена женщина, и останется в памяти только прекрасный момент рождения маленького чуда. Чтобы роды прошли нормально, стоит уделить особое внимание психологической подготовке беременной женщины. В статье рассматривается проблематика отношения женщины к беременности, родам и рождению ребенка. Представленные данные могут использоваться в школах материнства и отцовства при формировании программ обучения.

Ключевые слова: беременность, психология, пациент.

\section{PSYCHOLOGICAL PROBLEMS OF PREGNANCY AND THE PERINATAL PERIOD}

\section{I.S. Tymkiv}

Abstract. One of the important challenges that our society faces as a whole and medicine in particular is the formation and development of prenatal culture (or parenthood culture) which will help to raise a generation which treats the childbirth as natural and joyous event in their lives. Childbirth is an expected, mysterious and unforgettable stage of life for each woman. Pain will be soon forgotten - it's the woman's nature and the sole moment of the birth of a little wonder will remain in her memory. For the labour to be normal, we should pay special attention to psychological preparation of the pregnant woman. The article deals with the problems of the woman's attitude to her pregnancy, to the labour and delivery. These data could be used in maternity and paternity schools while developing the curriculum.

Key words: pregnancy, psychology, patient .

SHEE "National Medical University” (Ivano-Frankivsk)

Рецензент - доц. Н.С. Карвацька

Buk. Med. Herald. - 2014. - Vol. 18, № 1 (69). - P. 182-185

Надійшла до редакції 15.01.2014 року

(C) І.С. Тимків, 2014 